\title{
Plasticity Cultivation and Risk Aversion in Children's Development Process
}

\author{
Jiaxin rang \\ Yunnan Normal University, Kunming, China \\ liaoqi17@163.com
}

\begin{abstract}
Children are in the first stage of growth and development, and they have not yet formed a set of personality, habits and thinking concepts, so they have great plasticity. Theoretically speaking, we can mold children into any kind of characters, such as doctors, teachers, lawyers, policemen, artists and so on, according to the needs of environment and development. This shows that children's growth and development are closely related to the role of environment. How to discover and cultivate the plasticity of children in the process of children's development, avoid the risk in the process of development, and how to use the plasticity of children to implement scientific and appropriate training programs to promote the healthy growth of children is a problem that every parent or early childhood educator needs to think about. Starting from the characteristics of children's development, this paper explores the plasticity cultivation and risk aversion of children.
\end{abstract}

Keywords: children, development, plasticity cultivation, risk aversion.

\section{Introduction}

Children are at the starting point of their growth and development, and they have unlimited possibilities in life. As for what personality characteristics children shape and what direction they are going to develop in the future, to a great extent, it depends on the cultivation and education of parents and teachers. Plasticity is a term describing people's change and development potential. It refers to the possibility that people can be transformed and changed. There is a proverb in ancient China: rotten wood can not be carved. This proves that rotten wood does not have plasticity, rotten wood is obviously formed, lack of vitality of the wood, and those fresh, good quality wood, rotten wood can not be carved naturally (or difficult to carve). Similarly, comparing timber with people, imagine whether it is easy to cultivate a child's good habits, personality traits, or to change an old man over the age of armor. Children lack knowledge and life experience, they are like a blank paper, as long as parents and teachers carefully guide and train, they can outline a good blueprint for the growth and development of children; the elderly over the armor has a wealth of life experience, he has formed a set of personality characteristics and values. It's no longer easy to change him. Therefore, it can be considered that many children's thinking habits and behavior habits are not fixed, they are still in a period of easy change, plasticity is strong; with the growth of age, people's thinking habits and behavior habits gradually tend to be fixed, not easy to change, plasticity is weak.

\section{Ways to Cultivate Children's Plasticity}

\subsection{Implementing Open Education to Develop Children's Intelligence}

Watson, a famous American behaviorist psychologist, once said: Give me a group of healthy children and a stable and disposable environment, and I can guarantee that any one of them will be trained to be different people (doctors, lawyers, artists, businessmen, etc.) according to my wishes. This shows that children can be molded under certain environmental conditions, and this moldability is very strong. To mold a child into a healthy person with sound personality, we must adopt scientific and healthy education methods. In my opinion, when children are young, we should carry out open education and develop children's intelligence vigorously. For children before the age of six, their intelligence is still in the early stage of development, their understanding and judgment of things is still relatively vague and hazy. Because children's minds are not mature at this time, parents or teachers can adopt closed education methods. The so-called closed-door approach here is to ask 
questions and ask children to answer yes or no. For example, ask a child if he is hungry and wants to eat, so long as the child answers "hungry" or "not hungry", "want to eat" or "do not want to eat". For children after six years old, they have a certain amount of life experience, contact with more and more things, they began to have their own subjective feelings, thinking more active, more curious about anything new. Therefore, we should consider open education for children who are six years old. The so-called open education method is to try to consult children's feelings in an indefinite way, or arrange them to engage in some open and creative activities. For example, ask children how they feel about something (the answer is not fixed), and arrange children to build blocks (the shape of the blocks is not fixed). In an open education environment, children can think with more subjective experience and feelings, then their independent thinking ability and divergent thinking ability have been greatly exercised and improved. However, it should be noted that if children can not or are difficult to adapt to open education methods, parents or teachers will take the initiative to transition from open education to closed education. Here is a comparison between closed education and open education.

Table 1.Comparison between closed and open education.
object
type
Closed education
Open Education

Age of

application

3-5 years old

6-12 years old

Characteristic

Question answer and activity content are limited.

Examples

Is this flower beautiful (replying

"beautiful" or "not beautiful")

Ask children to help children

Method learn certain skills with teaching aids.
Problems and activities are open and focus on divergent thinking.

Do you think this flower is beautiful? Why?

Consulting the feelings of children and training children's practical ability and creativity by means

of teaching aids

\subsection{Equal Dialogue With Children and Effective Communication with Children with "Problem Solving" as a Breakthrough Point}

In the process of developing children's plasticity, communication is a very important link. Effective communication can promote communication with children, find problems and shortcomings in education, and then find ways to improve and solve them. Equal dialogue is the basis for effective communication with children. American behaviorists have found that equal dialogue with children is more conducive to building a positive and confident mentality. In order to improve the efficiency of plasticity cultivation and help children grow up better and faster, parents or teachers should always have a clear goal when communicating with children, and take "problem solving" as a breakthrough to have a dialogue with children (that is, to help children solve a problem). The author believes that an equal dialogue with children should follow certain steps. First, build equality on the distance. When children suffer setbacks and face difficulties, parents or teachers need to soothe them. Parents or teachers should not go straight to the subject of appeasement, which will let children fall into a passive state, appeasement effect may not be satisfactory. The author believes that it is an effective way to construct distance equality to squat close to children and make eye contact with children with friendly eyes so that children can get spiritual comfort quickly. Second, build an emotional common point. Parents or teachers should pay attention to building emotional commonalities with children, saying "I can understand what you are feeling now" to close the psychological distance between children. Third, effective guidance to children. Effective guidance 
for children is to state and analyze the setbacks or difficulties faced by children, to guide children to find their own flashes, and to understand their own shortcomings, to ask, inspire and encourage the way children's attention from the "failure" to look to the future, for the next Step by step make full preparation.

\section{Risk Aversion in Children's Development}

Avoiding the risks in the process of children's development is an important basis for ensuring children's healthy growth. Generally speaking, there are three kinds of risks in the process of children's development. The first is children's physical illness. These diseases are mainly found in the following table.

Table 2. Common diseases in children

\begin{tabular}{|c|c|}
\hline Development stage & Common diseases \\
\hline $\begin{array}{l}\text { Newborn (within } 3 \\
\text { months) }\end{array}$ & Jaundice, convulsion, pneumonia, septicemia, tetanus \\
\hline $\begin{array}{l}\text { Baby (3 months }-2 \text { years } \\
\text { old) }\end{array}$ & $\begin{array}{l}\text { Influenza, infantile eczema, functional diarrhea, tracheitis, pneumonia, } \\
\text { pertussis }\end{array}$ \\
\hline Children (2-12 years old) & $\begin{array}{l}\text { Influenza, acute gastroenteritis, acute bronchitis, acute pneumonia, measles, } \\
\text { chicken pox }\end{array}$ \\
\hline
\end{tabular}

Children's guardians should pay close attention to children's physical health, once the relevant symptoms of the disease are found immediately start treatment, to avoid the disease affecting children's normal life and learning. The second category is the accidental injury that children may be subjected to. Because children lack enough experience in life, their bodies are not yet fully developed. At the same time, they are very curious about everything. They are vulnerable to accidental injury in the process of playing and playing. In order to minimize the possibility of accidental injury to children, it is the responsibility and obligation of parents or teachers to consciously infiltrate safety knowledge into children during the process of plasticity development so as to make them understand "what can be done and what can not be done", "what is safe and what is dangerous" and "how to be at home when in danger". Protect yourself and save yourself. The third is the psychological and mental risks that children may receive. From a certain point of view, the importance of children's mental health is no less important than physical health, parents and teachers should regularly communicate with children closely, to avoid certain adverse events (such as domestic violence, peer conflict) and bring psychological harm to children. Once children's mental health problems are found, they should be actively intervened to protect their mental health.

\section{Summary}

To sum up, children are in the first stage of growth and development, their minds are not yet mature, do not form a fixed habit of thinking and behavior, with strong plasticity. In the process of children's education, parents and teachers should carry out open education, explore and enhance children's intelligence, conduct equal dialogue and effective communication with children, and help them to solve the setbacks and difficulties in the development process. At the same time, parents and teachers should pay close attention to children's physiological and psychological characteristics, and give them scientific and correct education and guidance to help children avoid risks in the process of development, to protect children's physical and mental health. 


\section{References}

[1]. Zhu Ben. Discussion on the plasticity and resistance of children [J].Journal of Tianjin Academy of Science and Technology, 1998 (5): 5-9.

[2]. Deng Qiying. On the Initiality and Plasticity of Children's Culture [J].Journal of Zhejiang Normal University (Social Science Edition), 2010, 35 (3): 44-48.

[3]. Liu Shumin. Plasticity of preschool planning ability [D]. Northeast Normal University, 2012.

[4]. Wang Jing. The emphasis of preschool education and teaching is based on children's psychological characteristics [J].Qunwentiandi, 2011 (16): 248-248. 